\title{
Circulation patterns governing October snowfalls in southern Siberia
}

\author{
Ewa Bednorz $^{1}$ - Joanna Wibig ${ }^{2}$
}

Received: 25 June 2015 / Accepted: 28 November 2015 /Published online: 16 December 2015

(C) The Author(s) 2015. This article is published with open access at Springerlink.com

\begin{abstract}
This study is focused on early fall season in southern Siberia $(50-60 \mathrm{~N})$ and is purposed as a contribution to the discussion on the climatic relevance of October Eurasian snow cover. Analysis is based on the daily snow depth data from 43 stations from years 1980-2012, available in the database of All-Russian Research Institute of Hydrometeorological Information-World Data Centre. The snow cover season in southern Siberia starts in early autumn and the number of days with snowfall varies from less than 5 days in the southernmost zone along the parallel $50 \mathrm{~N}$ to more than 25 days in the northeastern part of the analyzed area. October snowfall in southern Siberia is associated with occurrence of negative anomalies of sea level pressure (SLP), usually spreading right over the place of recorded intense snowfall or extending eastward from it. Negative anomalies of air temperature at the $850 \mathrm{hPa}$ geopotential level (T850) occurring with increased cyclonic activity are also observed. Negative T850 anomalies are located west or northwest of the SLP depressions. Counterclockwise circulation around low-pressure systems transports cold Arctic air from the north or even colder Siberian polar air from the east, to the west, and northwest parts of cyclones, and induces negative anomalies of temperature. The pattern of T850 anomalies during heavy snowfalls in the eastern part of the southern Siberia is shifted counterclockwise in regard to SLP anomalies: the strongest negative
\end{abstract}

Ewa Bednorz

ewabedno@amu.edu.pl

1 Department of Climatology, Institute of Physical Geography and Environmental Planning, Adam Mickiewicz University, Dzięgielowa 27, Poznań 61-680, Poland

2 Department of Meteorology and Climatology, University of Łódź, Narutowicza 88, Łódź 90-139, Poland
T850 anomalies are located west or northwest of the SLP depressions.

\section{Introduction}

Snow due to its physical features strongly modifies the surface-atmosphere energy budget and therefore is considered to be an important part of the climate system. Being the most unstable component of the Earth cryosphere, snow has been recognized as a sensitive indicator of global warming (Barry et al. 1993; Goodison and Walker 1993; Armstrong and Brun 2008). Although, it has been proven that the amount of snow and ice on Earth is decreasing, the snow cover extent on the lands of the Northern Hemisphere (NH) does not reveal such an obvious trend (Lemke et al. 2007). The reduction of snow is observed in spring and summer, due to higher air temperatures, while in winter the increase in snow extent is observed due to higher precipitation (Lemke et al 2007). Similar trend was confirmed for the autumn (October) Eurasian snow cover, which has increased in the last two decades (Cohen et al. 2012). The October Eurasian snow cover extent has become lately a widely discussed issue in a context of its climatic implications (Saito and Cohen 2003; Cohen and Fletcher 2007; Cohen et al. 2010; Cohen and Jones 2011; Allen and Zender 2011; Peings et al. 2013).

Some studies proved that the Eurasian (or rather Siberian) snow cover formed in early fall modulates the predominant $\mathrm{NH}$ teleconnection pattern, namely Arctic Oscillation (AO), in the subsequent winter. The conceptual model of this relationship, considering troposphere-stratosphere coupling, was described and documented by Cohen et al $(2010 ; 2014)$, as a sixstep process starting in October with an advance in Siberian snow cover and ending in winter with negative AO. Meanwhile, the diabatic air cooling over the early formed 
snow surface strengthens the Siberian High. Then, negative air temperature anomalies and positive pressure anomalies over Siberia induce poleward heat flux and enhance wave activity flux (WAF) to the stratosphere. Higher geopotential heights caused by convergence of WAF weaken the polar vortex and lead to stratospheric warming. Finally, stratospheric circulation anomalies propagate downwards and develop negative AO conditions in the troposphere.

In the original studies, Cohen and Entekhabi (1999) and Cohen and Fletcher (2007) considered the positive anomalies of October snow cover extent over Eurasia as the initial reason for developing negative $\mathrm{AO}$ in subsequent winter. However, in 2009/2010 an exceptionally cold winter was observed over $\mathrm{NH}$ and it was not preceded by an exceptional extent of Eurasian snow cover in October. This coincidence encouraged to search for more reliable predictor. In further research, the rapid increase in Siberian snow cover extent in October was proved to be a more significant factor in the relationship between the land surface and atmospheric processes, so the snow advance index (SAI) was developed as a better predictor of midwinter AO phase (Cohen and Jones 2011).

Regarding the importance of the appearance of October snow in Siberia and the strong impact of its rapid advance on the severity of $\mathrm{NH}$ winters, the next question arises, namely what are the reasons of the abundant snowfalls which lead to rapid increase in October snow cover extent in southern Siberia. The aim on this study is to determine the circulation patterns, which cause rapid daily increases in snow cover depth that occur in October. The analysis was based on daily snow cover depth data from surface meteorological stations located along the southern border of Siberia. According to Cohen and Jones (2011), the most rapid snow cover increases in October take place equatorward of $60^{\circ} \mathrm{N}$ and these regions of Eurasia were taken into consideration computing the SAI. Therefore, regarding aforementioned findings of Cohen and Jones (2011), the zone between 50 and $60^{\circ} \mathrm{N}$ was taken into consideration in this study.

There are some previous studies regarding snow cover in Russia and Eurasia and their relationships with atmospheric and oceanic circulation (Tachibana 1995; Ye et al. 1998; Clark et al. 1999; Ye 2000; Ye 2001a; Morinaga et al. 2003; Rikiishi and Sakakibara 2004; Iijima et al. 2007; Popova 2007; Farukh and Yamada 2014). Many researchers consider changes in the length of the snow season (Ye 2001b; Ye and Ellison 2003). Aforementioned studies have been based mostly on large time scales datasets (seasonal, monthly, or weekly). This study is based on daily datasets; it is focused on early fall season and it is purposed as a contribution to the discussion on the climatic relevance of October Eurasian snow cover.

\section{Data and methods}

\subsection{Snow cover}

This study is based on the daily snow depth data from 43 stations from years 1980 to 2012, available in the database 'Snow cover characteristics from Russian meteorological stations and from some meteorological stations over the former USSR territory' prepared by the All-Russian Research Institute of Hydrometeorological Information-World Data Centre (RIHMI-WDC). These meteorological data sets are automatically checked for quality control before being stored at the RIHMI-WDC and they were checked for the homogeneity (Mestcherskaya et al. 1995; Razuvaev and Shakirzyanov 2000; Veselov 2002; Popova 2007; Bulygina et al. 2010, 2011). The main problem with the data is that in many stations they are not complete, sometimes - in particular years- snow observation did not start at the very beginning of snow period, which means October data worse than data for latter months.

Choosing the stations was the very first and rather problematic part of the study. There are over 100 stations with snow cover data available in the RIHMI-WDC database within the determined area $\left(50-60^{\circ} \mathrm{N}, 55-140^{\circ} \mathrm{E}\right)$. However, they are not equally distributed (most of them placed in the river valleys, sometimes quite close to each other) and many of them with lacking data. The idea was to choose stations more or less equally distributed within the study area and having as little gaps as possible. The final list of stations with their geographical location with altitude is provided in the Table 1.

Snow depth data came from daily measurements taken at three snow measuring rods at 06.00 UTC. The daily depth of snow was calculated by averaging the readings on the three rods, rounded to the nearest whole centimeter. The days with a snow depth of $\geq 1 \mathrm{~cm}$ were considered as days with snow cover.

The investigated area covered the area located close to the southern border of Siberia, namely the latitudinal zone between $50^{\circ}$ and $60^{\circ} \mathrm{N}$ and between $55^{\circ}$ and $141^{\circ} \mathrm{E}$. In the western part, the study area includes the lowland region of the West Siberian Plain, where the altitude of measurement points does not exceed $500 \mathrm{~m}$ a.s.l. In the central and eastern part highlands and mountains prevail, such as Stanovoy Upland, Aldan Plateau, Western/Eastern Sayans, Yablonovy Mountains, Stanovoy Range, with the highest peaks exceeding $2000 \mathrm{~m}$ a.s.l. However, the most of meteorological stations in this area is located in lower elevation (often in the river valleys); therefore, their altitude is usually less than $700 \mathrm{~m}$ a.s.1. Only two stations are located above $1000 \mathrm{~m}$ a.s.l. The easternmost stations are placed at the shore of the Okhotsk Sea. According to Köppen-Geiger climate classification, almost entire study area belongs to the zone of snow climates (D), where the mean temperature of the coldest month $\leq-3{ }^{\circ} \mathrm{C}$. They are recognized as Df-snow climates, 
Table 1 List of the stations and their geographical location with percent of lacking snow cover data in October, years 1980-2012

\begin{tabular}{|c|c|c|c|c|c|}
\hline & \multirow[t]{2}{*}{ Station name } & \multicolumn{2}{|c|}{ Station coordinates } & \multirow{2}{*}{$\begin{array}{l}\text { Elevation of meteo. } \\
\text { site (m a.s.1.) }\end{array}$} & \multirow[t]{2}{*}{ Percent of lacking data } \\
\hline & & Latitude & Longitude & & \\
\hline 1 & Leusi & $59^{\circ} 37^{\prime}$ & $65^{\circ} 43^{\prime}$ & 70 & 0.3 \\
\hline 2 & Biser & $58^{\circ} 31^{\prime}$ & $58^{\circ} 51^{\prime}$ & 463 & 0.2 \\
\hline 3 & Perm' & $58^{\circ} 01^{\prime}$ & $56^{\circ} 18^{\prime}$ & 171 & 0.6 \\
\hline 4 & Tobol'sk & $58^{\circ} 09^{\prime}$ & $68^{\circ} 15^{\prime}$ & 49 & 0.8 \\
\hline 5 & Tjumen' & $57^{\circ} 07^{\prime}$ & $65^{\circ} 26^{\prime}$ & 101 & 0.1 \\
\hline 6 & Ekaterinburg & $56^{\circ} 50^{\prime}$ & $60^{\circ} 38^{\prime}$ & 281 & 0.4 \\
\hline 7 & Tara & $56^{\circ} 54^{\prime}$ & $74^{\circ} 23^{\prime}$ & 73 & 0.7 \\
\hline 8 & Kurgan & $55^{\circ} 28^{\prime}$ & $65^{\circ} 24^{\prime}$ & 73 & 3.6 \\
\hline 9 & Omsk & $55^{\circ} 01^{\prime}$ & $73^{\circ} 23^{\prime}$ & 121 & 0.7 \\
\hline 10 & Ufa & $54^{\circ} 43^{\prime}$ & $55^{\circ} 50^{\prime}$ & 104 & 1.0 \\
\hline 11 & Troizk & $54^{\circ} 05^{\prime}$ & $61^{\circ} 37^{\prime}$ & 192 & 0.0 \\
\hline 12 & Sredny Vasjugan & $59^{\circ} 13^{\prime}$ & $78^{\circ} 14^{\prime}$ & 68 & 0.0 \\
\hline 13 & Kolpasevo & $58^{\circ} 18^{\prime}$ & $82^{\circ} 53^{\prime}$ & 75 & 0.1 \\
\hline 14 & Enisejsk & $58^{\circ} 27^{\prime}$ & $92^{\circ} 09^{\prime}$ & 77 & 0.0 \\
\hline 15 & Bogucany & $58^{\circ} 23^{\prime}$ & $97^{\circ} 27^{\prime}$ & 131 & 0.2 \\
\hline 16 & Pudino & $57^{\circ} 34^{\prime}$ & $79^{\circ} 26^{\prime}$ & 96 & 0.0 \\
\hline 17 & Tomsk & $56^{\circ} 30^{\prime}$ & $84^{\circ} 55^{\prime}$ & 141 & 0.2 \\
\hline 18 & Krasnojarsk & $56^{\circ} 02^{\prime}$ & $92^{\circ} 45^{\prime}$ & 277 & 0.9 \\
\hline 19 & Barabinsk & $55^{\circ} 20^{\prime}$ & $78^{\circ} 22^{\prime}$ & 119 & 0.5 \\
\hline 20 & Nenastnaja & $54^{\circ} 45^{\prime}$ & $88^{\circ} 49^{\prime}$ & 1186 & 0.1 \\
\hline 21 & Barnaul & $53^{\circ} 22^{\prime}$ & $83^{\circ} 42^{\prime}$ & 183 & 0.6 \\
\hline 22 & Minusinsk & $53^{\circ} 43^{\prime}$ & $91^{\circ} 42^{\prime}$ & 254 & 1.2 \\
\hline 23 & Bijsk Zonal'naja & $52^{\circ} 41^{\prime}$ & $84^{\circ} 56^{\prime}$ & 222 & 0.0 \\
\hline 24 & Vitim & $59^{\circ} 27^{\prime}$ & $112^{\circ} 35^{\prime}$ & 186 & 3.0 \\
\hline 25 & Kirensk & $57^{\circ} 46^{\prime}$ & $108^{\circ} 04^{\prime}$ & 256 & 0.0 \\
\hline 26 & Orlinga & $56^{\circ} 03^{\prime}$ & $105^{\circ} 50^{\prime}$ & 338 & 6.1 \\
\hline 27 & Kazachinsk & $56^{\circ} 17^{\prime}$ & $107^{\circ} 37^{\prime}$ & 355 & 0.0 \\
\hline 28 & Chara & $56^{\circ} 54^{\prime}$ & $118^{\circ} 16^{\prime}$ & 709 & 3.1 \\
\hline 29 & Cul'man & $56^{\circ} 50^{\prime}$ & $124^{\circ} 52^{\prime}$ & 855 & 3.0 \\
\hline 30 & Tulun & $54^{\circ} 36^{\prime}$ & $100^{\circ} 38^{\prime}$ & 523 & 0.0 \\
\hline 31 & Zhigalovo & $54^{\circ} 48^{\prime}$ & $105^{\circ} 10^{\prime}$ & 416 & 0.2 \\
\hline 32 & Troickij Priisk & $54^{\circ} 37^{\prime}$ & $113^{\circ} 08^{\prime}$ & 1315 & 3.2 \\
\hline 33 & Mogoca & $53^{\circ} 45^{\prime}$ & $119^{\circ} 44^{\prime}$ & 624 & 3.3 \\
\hline 34 & Skovorodino & $54^{\circ} 00^{\prime}$ & $123^{\circ} 58^{\prime}$ & 397 & 3.4 \\
\hline 35 & Irkutsk & $52^{\circ} 16^{\prime}$ & $104^{\circ} 21^{\prime}$ & 467 & 0.3 \\
\hline 36 & Chita & $52^{\circ} 05^{\prime}$ & $113^{\circ} 29^{\prime}$ & 671 & 12.1 \\
\hline 37 & Sretensk & $52^{\circ} 14^{\prime}$ & $117^{\circ} 42^{\prime}$ & 528 & 3.6 \\
\hline 38 & Aldan & $58^{\circ} 37^{\prime}$ & $125^{\circ} 02^{\prime}$ & 678 & 5.5 \\
\hline 39 & Ajan & $56^{\circ} 27^{\prime}$ & $138^{\circ} 09^{\prime}$ & 6 & 0.4 \\
\hline 40 & Bomnak & $54^{\circ} 43^{\prime}$ & $128^{\circ} 52^{\prime}$ & 365 & 0.1 \\
\hline 41 & Nikolaevsk-na-Amure & $53^{\circ} 09^{\prime}$ & $140^{\circ} 42^{\prime}$ & 67 & 0.7 \\
\hline 42 & Im. Poliny Osipenko & $52^{\circ} 25^{\prime}$ & $136^{\circ} 30^{\prime}$ & 73 & 0.2 \\
\hline 43 & Blagovescensk & $50^{\circ} 15^{\prime}$ & $127^{\circ} 30^{\prime}$ & 130 & 0.8 \\
\hline
\end{tabular}

fully humid in the western and central part and Dw-snow climates with dry winter in the east. Only very small areas located in the highest parts of the study area belong to the group of polar climates (E), classified as ET - tundra climates and single pixels in the western part are recognized as cold steppe climate (BSk) (Kottek et al. 2006). 
An attempt was made to divide the analyzed area into regions, which differ in terms of snow cover occurrence. To this end, the Ward's (1963) method of hierarchical grouping of multi-variable objects was applied, with the stations being the objects and the normalized daily values of snow cover depth being the variables. The results of clustering were shown in a dendrogram (Fig. 3).

To detect daily changes in snow cover depth, the snow depth of a given day was subtracted from the snow depth of the following day. Positive values indicate increases in snow depth. To avoid (or at least reduce) situations, when the snow cover increase was caused by the snow drift, only the days with precipitation $>0 \mathrm{~mm}$ were taken into further consideration. Computing the daily increases we did not take into consideration days, when snow depth data was lacking in a given day and in a following day.

The main aim on the study concerned intense snowfalls, expressed by the substantial accumulation of snow. Therefore, days with an increase in snow cover depth of $\geq 5 \mathrm{~cm}$ were selected, and air circulation on these days was analyzed for the distinguished regions separately. This means that only the days when at least $5 \mathrm{~cm}$ of the fresh snow appeared were taken into consideration in the study of circulation and meteorological conditions of heavy snowfall events. According to the Glossary of Meteorology by the American Meteorological Society, 'snowfall' means the accumulation of snow during a specified period of time (usually expressed in centimeters or inches of snow depth) (Huschke 1959). Later in the study, the term 'snowfall' is used interchangeably with 'increases in snow depth' to simplify the text.

\subsection{Circulation conditions}

Relating the rapid changes in snow depth to circulation, the 'environment to circulation' approach was applied. Using this method, the circulation classification was carried along a specific environment-based criteria set for a particular environmental phenomenon, i.e., rapid increase in snow depth in this case (Yarnal 1993; Yarnal et al. 2001; Dayan et al. 2012). Circulation during the days of abundant snow accumulation was considered in terms of pressure patterns reduced to sea level, which determine the atmospheric circulation and the transport of air masses in low troposphere. Additionally, the field of air temperature at the geopotential height of $850 \mathrm{hPa}$, which is important for forming snowfall, was analyzed. Mean daily sea level pressure (SLP) and mean daily air temperature at the geopotential height $850 \mathrm{hPa}$ (T850) data were selected from the National Centers for Environmental Prediction (NCEP) - National Center for Atmospheric Research (NCAR) reanalysis data (Kalnay et al. 1996). The resolution of all reanalysis data used in the study was $2.5 \times 2.5 \mathrm{deg}$.

Analysis was carried out separately for each region distinguished as the result of hierarchical grouping. Snowfalls are sometimes influenced by local conditions; therefore, only the days with abundant snowfalls at more than one station were taken into consideration. Anomalies of SLP and T850 were computed and mapped for the selected days with snow cover increase by at least $5 \mathrm{~cm}$ in at least two stations. Anomalies were calculated as differences between composite values for the days with intense snowfalls and 33-year October means. In order to detect the origin of the cyclones that lead to snowfall events, anomalies of SLP for 3 days prior to the heavy snowfall events were calculated and mapped.

Apart from analysis based on daily snow depth data, described above the correlation between October sums of snow cover increases and October indices of macroscale circulation patterns, like Arctic Oscillation (AO), East Atlantic/Western Russia (EA/WR), Polar/Eurasia (POL/EU), and Scandinavia (SC) were computed. Monthly indices of circulation patterns were derived from Climate Prediction Center databases (Barnston and Livezey 1987). Also, correlation coefficients between October sums of snow cover increases and intensity of the Siberian High (SH) in October and in subsequent months were calculated. The SH intensity was computed as a normalized regional monthly mean SLP averaged over $70^{\circ} \mathrm{E}$ to $120 \mathrm{E}, 40^{\circ} \mathrm{N}$ to $60^{\circ} \mathrm{N}$ for winters $1980 / 1981-2011 / 2012$ (Gong and Ho 2002), using the NCEP/NCAR reanalysis data.

\section{Results}

The mean number of days with snow cover in October varies from less than 5 days in the southernmost zone along the parallel $50^{\circ} \mathrm{N}$ to more than 25 days in the northeastern part of the analyzed area (Fig. 1). Many more days with snow cover in October are observed in the eastern and central part of the studied area, due to higher elevation, than in the lowland western part. Number of days with snow cover in early fall varies from year to year. In most of the stations (36), there were seasons when snow cover was not recorded at all in October; on the other hand, there are also several stations (7), where in single seasons snow cover persisted during the entire month.

The primary analysis of the air circulation causing increases in snow cover depth in October was based on monthly sums of snow cover increases in October. These values were correlated with macroscale circulation patterns, recognized over this part of the Northern Hemisphere. Correlation coefficients between October snowfalls and AO were negative in most of the stations ( 32 out of 43), but they were statistically significant only in three stations located in the central part of the studied area.

The next circulation pattern taken into consideration, namely EA/WR is one of three prominent teleconnection patterns that affect Eurasia and it consists of four main anomaly centers. The positive phase is associated with positive pressure 
Fig. 1 Mean number of days with snow cover in October within the studied area

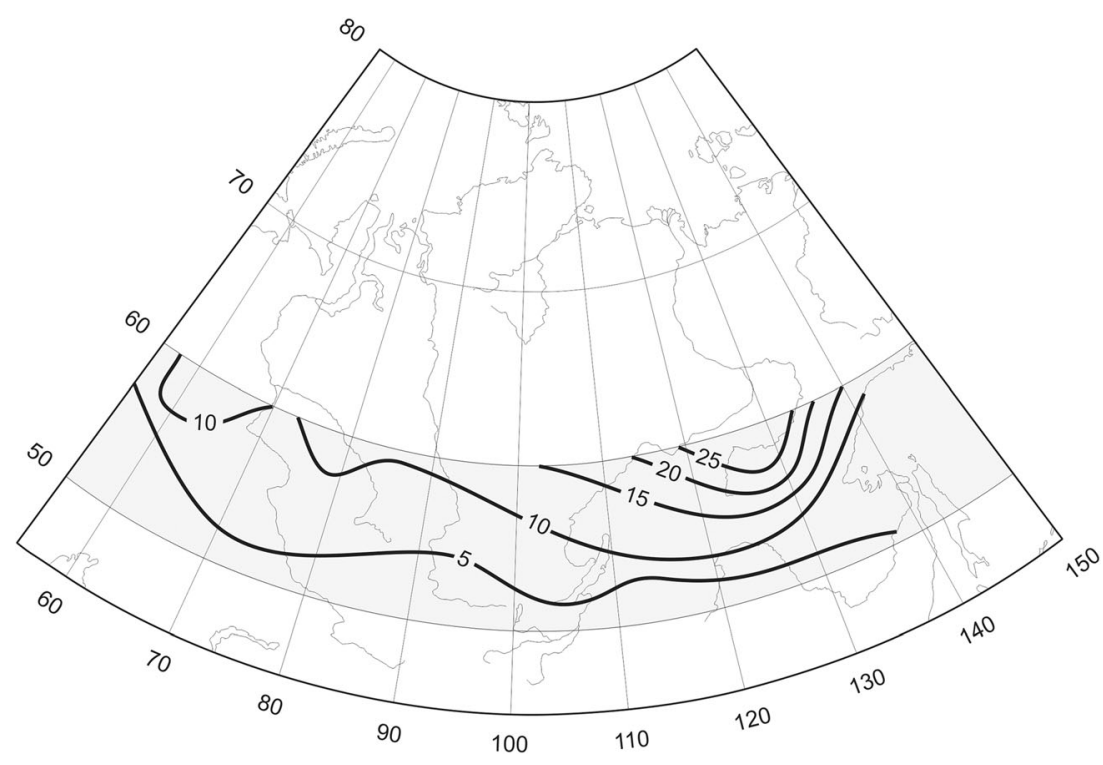

anomalies located over Europe and northern China, and negative anomalies located over the central North Atlantic and north of the Caspian Sea. In the positive phase, low-pressure center over the Caspian Sea causes snowfalls in the westernmost part of the studied area (dark-shaded triangles in Fig. 2), while in the negative phase of EA/WR lower than normal pressure over northern China is associated with snowfalls in a few stations in the eastern and central part of southern Siberia.

Sums of the October snowfalls revealed negative correlation with the POL/EU pattern (light grey squares in Fig. 2). The negative phase of this pattern is associated with negative pressure anomalies over northern China and Mongolia, which are favorable for October snowfalls that occur in the central and eastern part of the analyzed region.
The SC pattern consists of a primary circulation center over Scandinavia, with weaker centers of opposite sign over western Europe and eastern Russia/western Mongolia. This circulation pattern reveals significant positive correlation with sums of the October snowfalls in the western part of the studied area (dark-shaded circles in Fig. 2). Concluding, at the base of the analysis of the monthly sums of snowfalls, it can be deduced that high monthly sums correlate with negative pressure anomalies that occur over the snowfall area or in its vicinity.

Additionally, correlation coefficients between October sums of snow cover increases and intensity of the $\mathrm{SH}$ in October and in subsequent months were calculated. Correlation coefficients with October SH index were negative
Fig. 2 Statistically significant $(p \geq 0.95)$ correlation coefficients between October sums of snow cover increases and October indices of macroscale circulation patterns: East Atlantic/Western Russia (EA/WR)-triangles, Polar/Eurasia (POL/EU) squares, and Scandinavia (Scand)_circles. Dark-shaded figures mean positive correlation, light grey means negative correlation

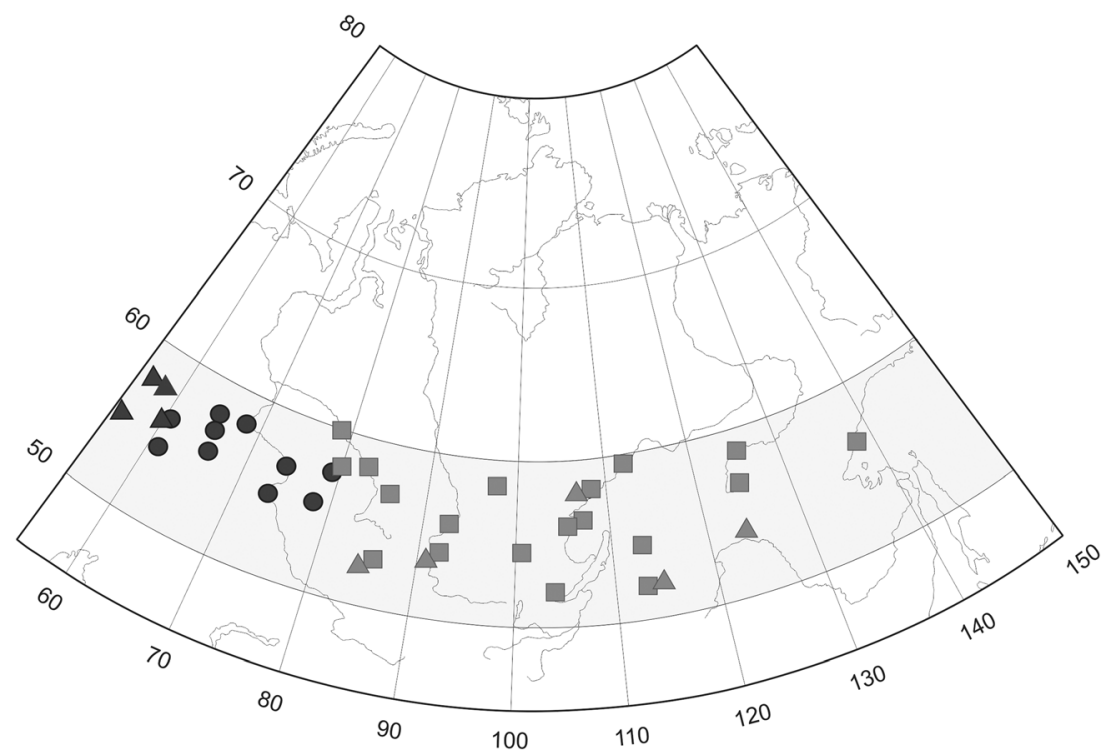


in October, which means that October snowfalls are associated with weaker than normal $\mathrm{SH}$, while correlation between October snowfalls and SH index in subsequent months is positive (not statistically significant in most stations), which confirms the first stages of the six-step mechanism worked out by
Cohen and Fletcher (2007) and Cohen et al. (2010; 2014; described in Introduction).

The area of the research is vast and it stretches from $55^{\circ}$ to $141^{\circ}$ eastern latitude. Therefore, before the further analysis, the entire area was divided into regions, which differ in terms

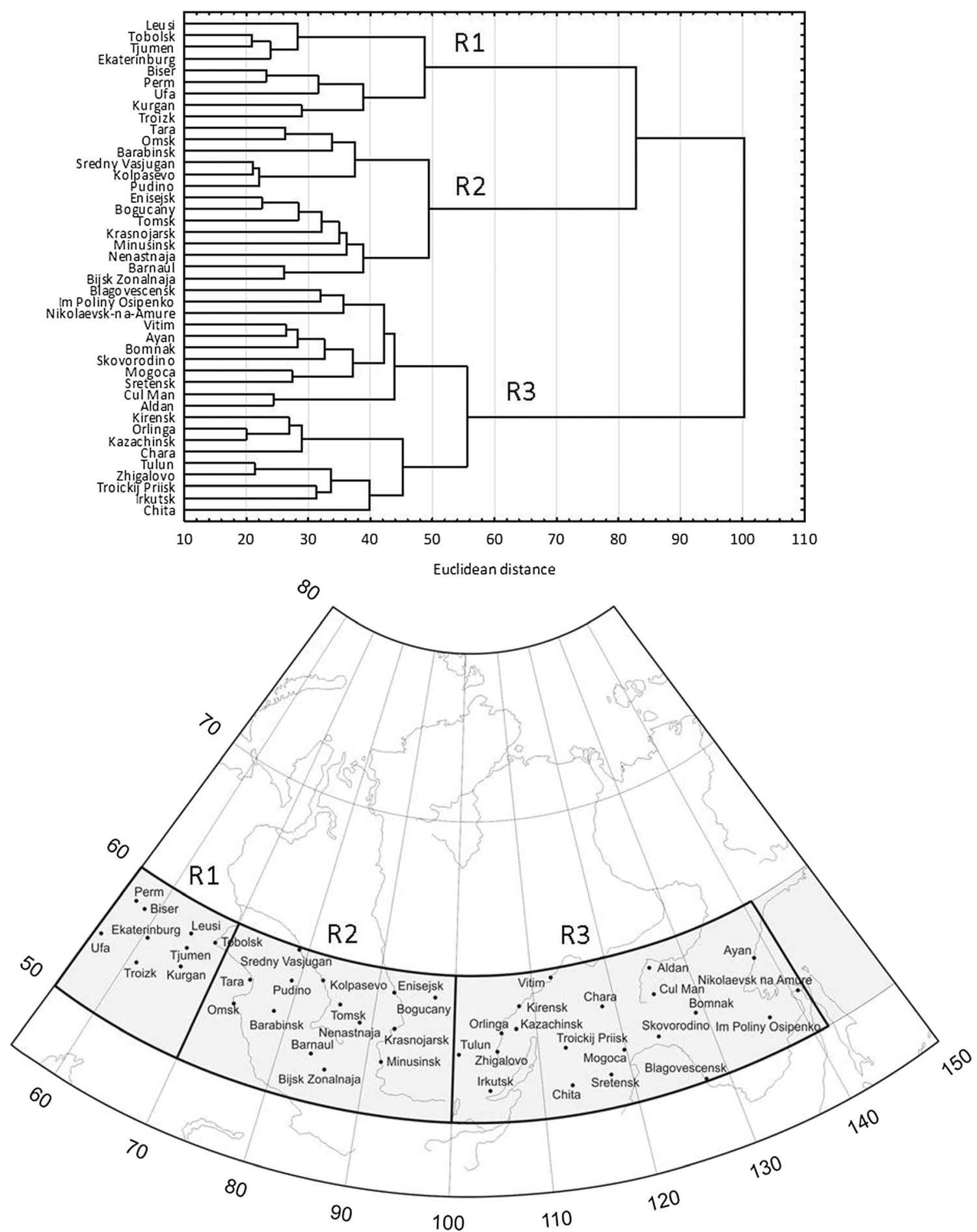

Fig. 3 Dendrogram showing the clustering of stations by the Ward method (up) and map showing spatial distribution of stations from three clusters and division into three regions named R1, R2, and R3 (bottom) 
of snow cover occurrence. To this end, the Ward's (1963) method of hierarchical grouping of multi-variable objects was applied, with the stations being the objects and the normalized daily values of snow cover depth being the variables. Grouping together the similar stations allow distinguishing regions, where snow appears more or less simultaneously. The results of clustering were shown in a dendrogram (Fig. 3). The zone $50-60^{\circ} \mathrm{N}$ was divided meridionally into three parts: western region R1 consisting of nine stations, central region R2 (14 stations), and eastern region R3 (20 stations) (Fig. 3).

The further analysis concerned the substantial accumulation of snow in October. Days with an increase in snow cover depth of $\geq 5 \mathrm{~cm}$ in at least two stations in each region were selected. Circulation conditions of substantial snow accumulation were considered in terms of SLP patterns, which determine the direction of airflow and the transport of air masses.

In October, the SLP field over Siberia is dominated with a vast anticyclone called the Siberian High, which starts to develop in the autumn. Its center is located over the southern border of Russia, where an average SLP in October exceeds $1024 \mathrm{hPa}$ (Fig. 4). In late winter, the mean SLP in the core of the Siberian High amounts to over $1030 \mathrm{hPa}$. A low-pressure zone extends southwest from the Iceland and spreads to the northeast, towards the Arctic Basin, reaching the Barents Sea. Another low-pressure area, namely Aleutian low, spreads over the north Pacific. Both SLP depressions are divided by the ridge of high pressure that crosses the Arctic Ocean and connects the Siberian High with the North American High.
Composite anomaly maps constructed for the days with intense snow accumulation show particular circulation patterns, which develop over analyzed region. The SLP pattern reveals the area of strong negative SLP anomalies, which appear over the region of heavy snowfall and at the same time positive SLP anomalies appearing northwest to it (Fig. 5, right column). Lower than normal pressure in the area of average $\mathrm{SH}$ position indicates weakening of this anticyclone system and revealing increased cyclonic activity instead over the analyzed area. The cyclones that bring snowfall do not migrate from distant areas but they seem to form locally on the border of the two different air masses: the very cold Arctic or polar continental air from the north, northeast or east and warmer, more humid air from south or southeast. The development of SLP conditions can be detected from the SLP anomalies computed for 3 days prior to intensive snowfall events (Fig. 5 left column).

In the case of the first, westernmost region (R1) negative anomalies of SLP amount to below $-6 \mathrm{hPa}$ in the center, which is located right over the R1 area. At the same time positive SLP anomalies exceeding $6 \mathrm{hPa}$ are located over the Scandinavia. This resembles the SC macroscale circulation pattern, described above, which reveal positive correlation with October snowfall in the R1 region (Fig. 2). Described SLP field intensifies easterly inflow of air masses in the northern part of region 1. Polar continental air masses from the east are cold and they cause negative anomalies of air temperature (T850) over western Siberia (Fig. 6, R1). The center of negative anomalies of T850 is located right north from the region 1 and the air temperature is lower than normal by more than $7 \mathrm{~K}$.
Fig. 4 Sea level pressure (hPa) over the Northern Hemisphere in October. Average for years 1980 2012

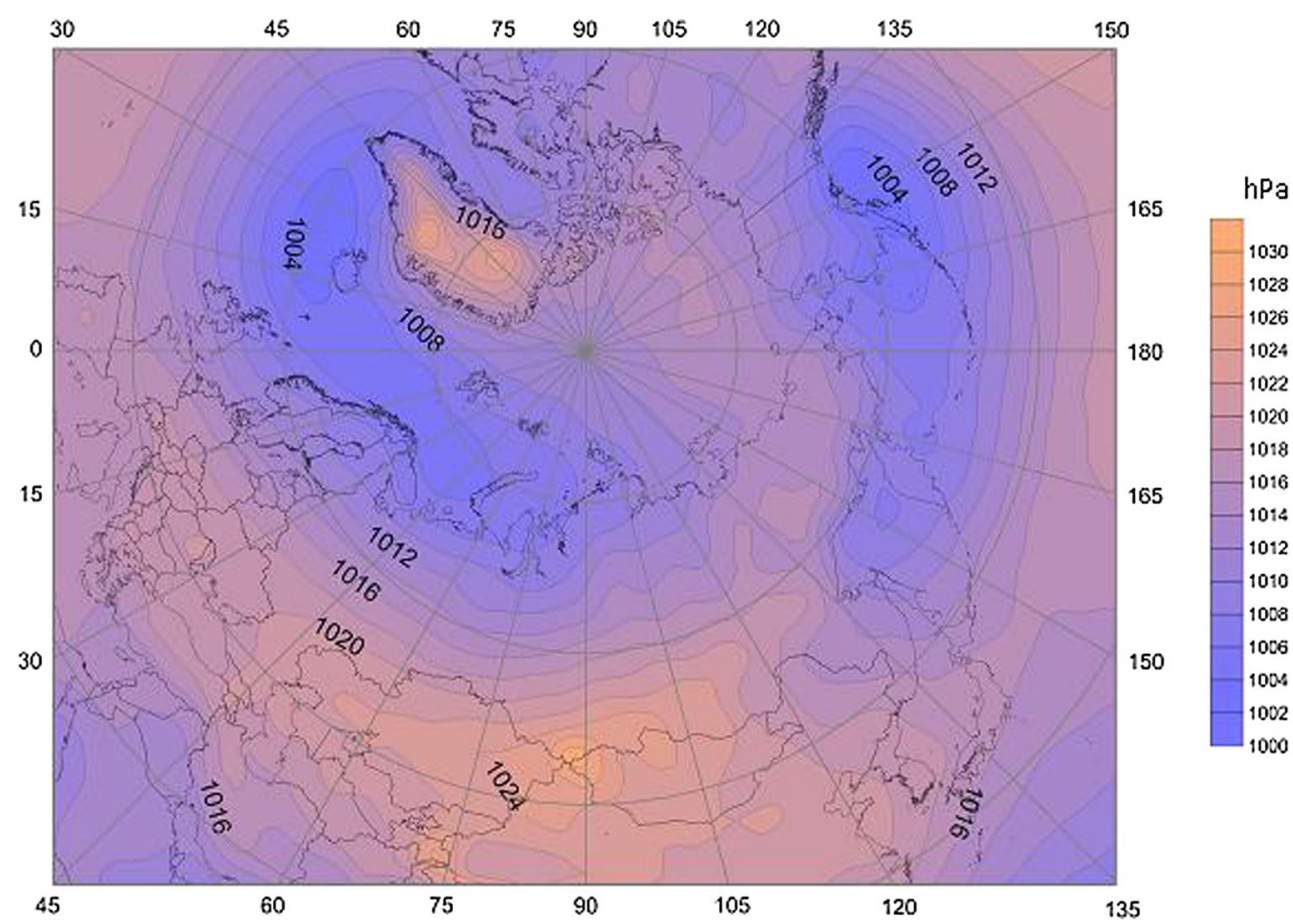



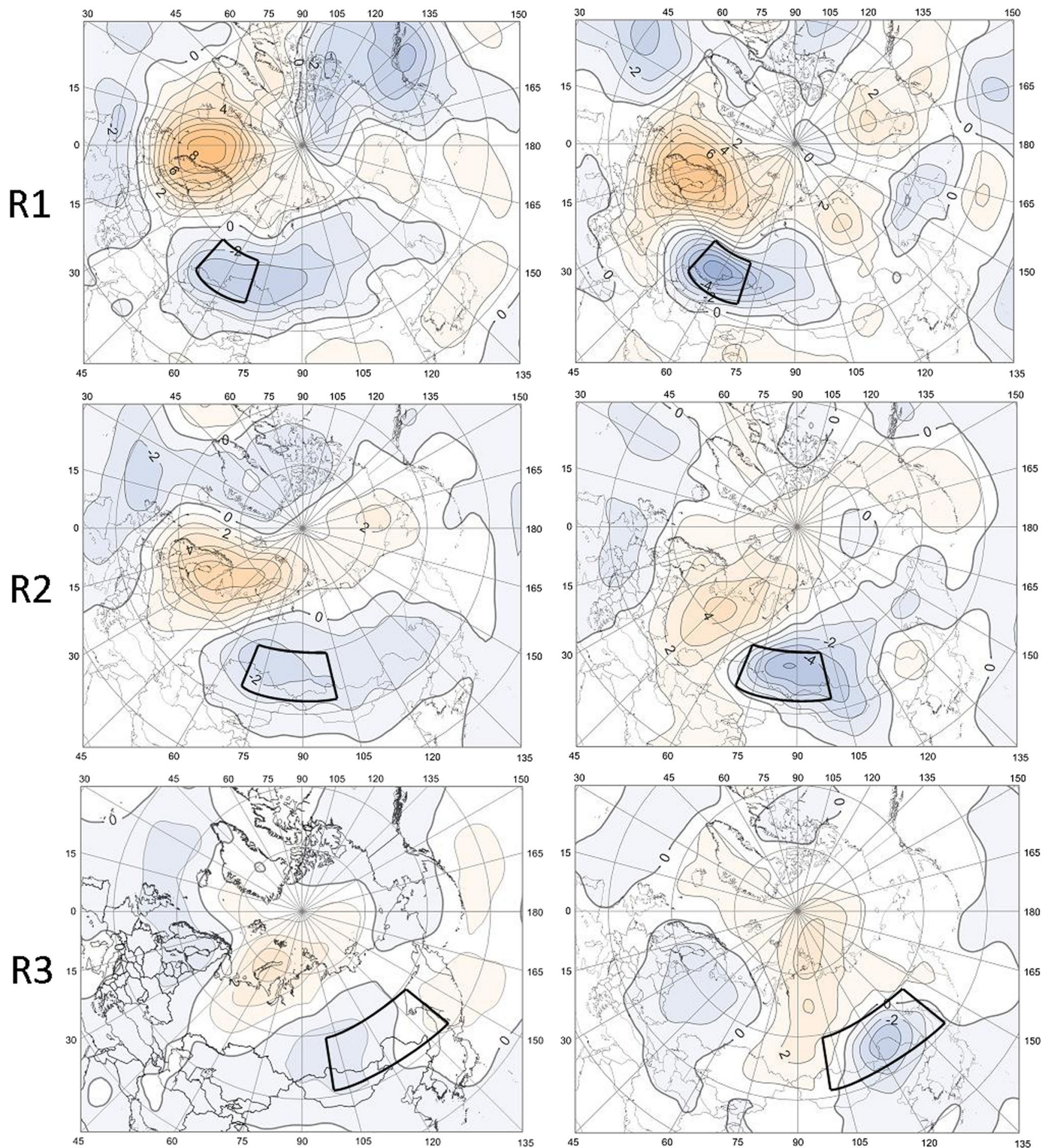

Fig. 5 Left column - SLP anomalies for 3 days prior to intensive snowfall events in each distinguished region. Right column — SLP anomalies during the days with intensive snowfall, i.e., with snow cover increases by at least $5 \mathrm{~cm}$ in each region

The cyclones that bring snowfall in October in south Siberia differ in their intensity and localization depending on the area of snowfall. In the region 2 (Fig. 5, R2), low-pressure system extends over the snowfall region and east to it. The map of SLP anomaly for the 3 days prior to heavy snowfall events was constructed. It shows negative SLP anomalies, which extend east to the region 2 and reach the Okhotsk and Japan Sea. This may suggest that low-pressure systems that cause snowfall in the region 2 move from the east, or at least they are linked to warm air masses from the Pacific coast. This time the strongest negative anomalies of T850 appear in northwestern edge of the analyzed region (Fig. 6, R2). Location of 
Fig. 6 Anomalies of air

temperature at geopotential level of $850 \mathrm{hPa}$ during the days with intensive snowfall, i.e., with snow cover increases of at least $5 \mathrm{~cm}$ in two or more stations in each

distinguished region for October
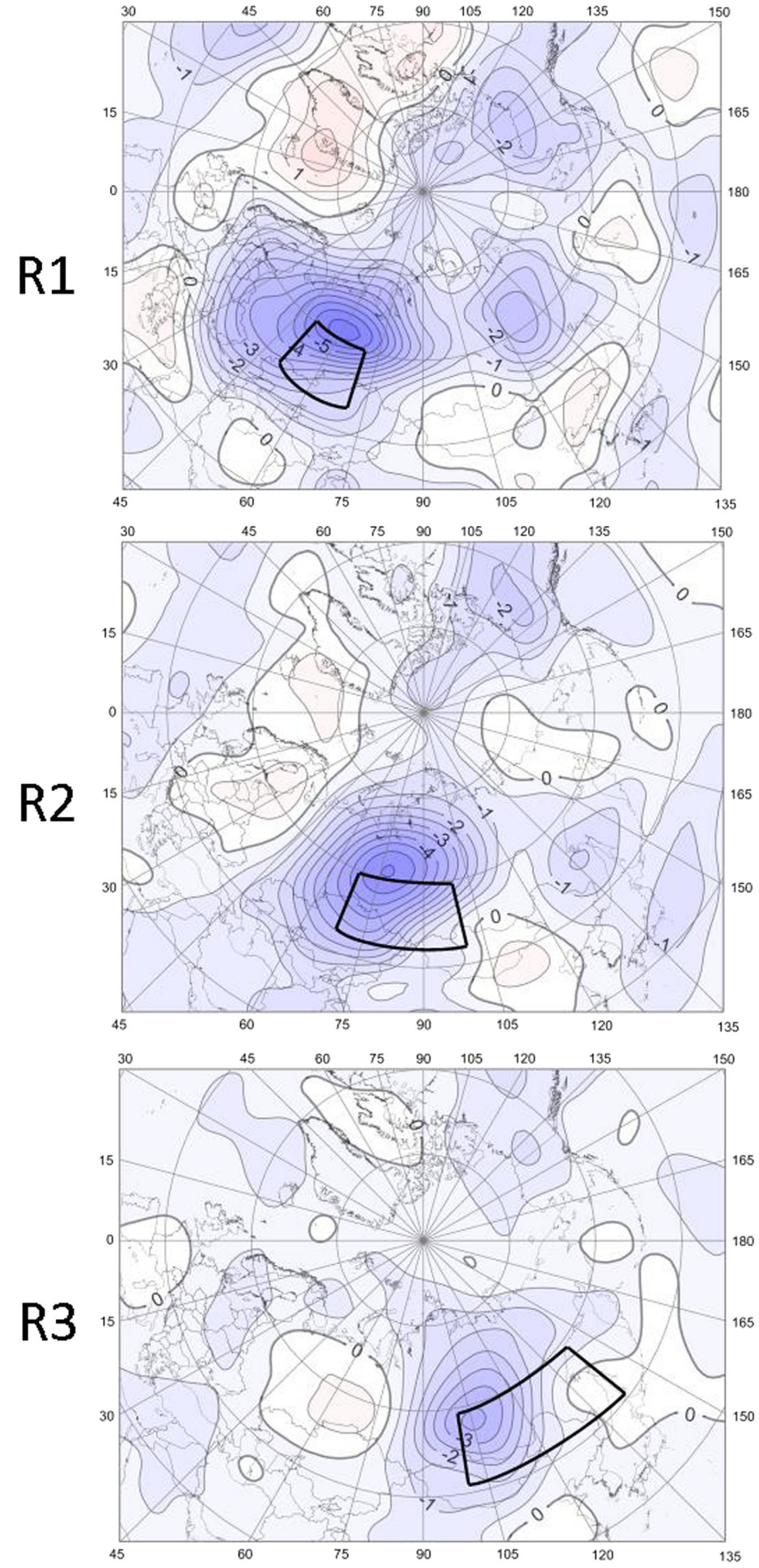
the negative T850 anomalies suggests northeasterly inflow of air masses, which is concordant with the counterclockwise circulation around the cyclonic center.

Anomaly map of SLP constructed for snowfall days in the region 3 shows again a negative SLP anomalies located over the region of snowfall (Fig. 5, R3), concurrent with negative T850 anomalies appearing in the western part of the region (Fig. 6, R3). Negative SLP anomalies spreading over southeastern Siberia, northern China, and Mongolia during snowfall periods in regions 1 and 2 resemble the negative phase of POL/EU macroscale circulation pattern, described above. This pattern reveals negative correlation with October snowfall in the central and eastern part of southern Siberia (Fig. 2).

In each of analyzed regions, heavy snowfalls are possible when the Siberian High is weaker than usual and it is shifted westward or northward. Deep cyclones appear instead in southern Siberia and they provide a better chance for precipitation.

\section{Conclusions and discussion}

This study was focused on early fall season and it was meant as a contribution to the discussion on the climatic reasons and implications of October Eurasian snow cover, which has become lately a widely elaborated issue (Saito and Cohen 2003; Cohen and Fletcher 2007; Cohen et al. 2010; Cohen and Jones 2011; Allen and Zender 2011; Peings et al. 2013). It was determined in this study that the snow cover season starts in early autumn in southern Siberia and the number of days with snowfall varies from less than 5 days in the southernmost zone along the parallel $50^{\circ} \mathrm{N}$ to more than 25 days in the northeastern part of the analyzed area.

Snowfall in southern Siberia in the early fall season is associated with occurrence of negative anomalies of SLP, usually spreading right over the place of recorded intense snowfall or extending eastward from it. Negative anomalies of air temperature occurring with increased cyclonic activity are also observed. Negative T850 anomalies are located west or northwest of the SLP depressions. Counterclockwise circulation around low-pressure systems brings cold Arctic air from the north or even colder Siberian polar air from the east, to the west and northwest parts of cyclones, and induces negative anomalies on the temperature field. The pattern of T850 anomalies during heavy snowfalls in the eastern part of the southern Siberia is shifted counterclockwise: the strongest negative T850 anomalies are located west or northwest of the SLP depressions.

The most important center of action in Eurasia during the wintertime is an extensive anticyclone of thermal origin called Siberian High. Changes in its intensity and their contribution to changes in temperature and precipitation over Eurasia have been discussed recently (Gong and Ho 2002; Panagiotopoulos et al. 2005; Jeong et al. 2011). The formation of the Siberian High starts in autumn and it is regarded to be associated with early forming snow cover (Cohen and Fletcher 2007; Cohen et al. 2010, 2014; Cohen and Entekhabi 1999; Cohen and Jones 2011). Concerning these statements, atmospheric conditions of snow cover forming in October may work as a predictor of strength and extent of the Siberian High in winter. Correlation coefficients between October snowfall and October SH index computed in this study were negative, which means that October snowfalls are associated with weaker than normal SH, while correlation between October snowfalls and SH index in subsequent months is positive, which suggests that abundant October snow in south Siberia foreshow strong Siberian High in winter. Consequently, recognizing the meteorological conditions of October snowfall may be essential for seasonal weather forecasts for subsequent winter.

October circulation patterns over Eurasia were found to be precursors of the winter $\mathrm{AO}$, which is considered a driving factor for winter climatic conditions in vast regions of the Northern Hemisphere. Kryjov (2015) identified an October Taymyr circulation index well correlated with winter AO index. Anticyclonic conditions over the Taymyr Peninsula lead to the increase in the air temperature over the Arctic and to the decrease in the air temperature over the northeastern Asia and this way they enhance the climatological trough associated with long planetary waves. Such conditions activate negative AO phase in the succeeding winter. According to Kryjov (2015), winter negative AO is also anteceded by negative anomalies of SLP in Asian mid-latitudes, similar to the recognized in this study SLP patterns favorable for heavy snowfalls in south Siberia.

Acknowledgments This work was supported by the Polish National Science Centre under grant number 2011/01/B/ST10/01923.

Open Access This article is distributed under the terms of the Creative Commons Attribution 4.0 International License (http:// creativecommons.org/licenses/by/4.0/), which permits unrestricted use, distribution, and reproduction in any medium, provided you give appropriate credit to the original author(s) and the source, provide a link to the Creative Commons license, and indicate if changes were made.

\section{References}

Allen RJ, Zender CS (2011) Forcing of the Arctic Oscillation by Eurasian snow cover. J Climate 24:6528-6539

Armstrong RL, Brun E (2008) Snow and climate: physical processes. Surface Energy Exchange and Modeling. Cambridge University Press, Cambridge, p 222

Barnston AG, Livezey RE (1987) Classification, seasonality and persistence of low-frequency atmospheric circulation patterns. Mon Weather Rev 115:1083-1126

Barry RG, Goodison BE, LeDrew EF (eds) (1993) Snow watch '92detection strategies for snow and ice Glaciological Data Report GD- 
25. World Data Center A: Glaciology (Snow and Ice), Boulder, CO, p 101

Bulygina ON, Groisman PY, Razuvaev VN, Radionov VF (2010) Snow cover basal ice layer changes over northern Eurasia since 1966. Environ Res Lett 5:015004

Bulygina ON, Groisman PY, Razuvaev VN, Korshunova NN (2011) Changes in snow cover characteristics over northern Eurasia since 1966. Environ Res Lett 6:045204

Clark MP, Serreze MC, Robinson AD (1999) Atmospheric controls on Eurasian snow extent. Int J Climatol 19:27-40

Cohen J, Entekhabi D (1999) Eurasian snow cover variability and Northern Hemisphere climate predictability. Geophys Res Lett 26: $345-348 d$

Cohen J, Foster J, Barlow M, Saito K, Jones J (2010) Winter 2009-2010: a case study of an extreme Arctic Oscillation event. Geophys Res Lett 37:L17707

Cohen J, Furtado JC, Barlow MA, Alexeev VA, Cherry JE (2012) Arctic warming, increasing snow cover and widespread boreal winter cooling. Environ Res Lett 7:014007

Cohen J, Jones J (2011) A new index for more accurate winter predictions. Geophys Res Lett 38:L21701

Cohen J, Screen JA, Furtado JC, Barlow M, Whittleston D, Coumou D, Francis J, Dethloff K, Entekhabi D, Overland J, Jones J (2014) Recent Arctic amplification and extreme mid-latitude weather. Nat Geosci 7:627-637

Cohen J, Fletcher C (2007) Improved skill for Northern Hemisphere winter surface temperature predictions based on land-atmosphere fall anomalies. J Climate 20:4118-4132

Dayan U, Tubia A, Levy I (2012) On the importance of synoptic classification methods with respect to environmental phenomena. Int $\mathrm{J}$ Climatol 32:681-694

Farukh MA, Yamada TJ (2014) Synoptic climatology associated with extreme snowfall events in Sapporo city of northern Japan. Atmos Sci Lett 15:259-265

Gong D-Y, Ho C-H (2002) The Siberian High and climate change over middle to high latitude Asia. Theor Appl Climatol 72:1-9

Goodison BE, Walker AE (1993) Use of snow cover derived from satellite passive microwave data as indicator for climate change. Ann Glaciol 17:137-42

Huschke RE (1959) Glossary of Meteorology. American Meteorological Society, Boston, USA, p 638

Iijima Y, Masuda K, Ohata T (2007) Snow disappearance in eastern Siberia and its relationship to atmospheric influences. Int J Climatol 27:169-177

Jeong J-H, Ou T, Linderholm HW, Kim B-M, Kim S-J, Kug J-S, Chen D (2011) Recent recovery of the Siberian High intensity. J Geophys Res 116:D23102

Kalnay E, Kanamitsu M, Kistler R, Collins W, Deaven D, Gandin L, Iredell M, Saha S, White G, Woollen J et al (1996) The NMC/ NCAR 40-Year Reanalysis Project. Bull Am Meteorol Soc 77: 437-471

Kottek M, Grieser J, Beck C, Rudolf B, Rubel F (2006) World map of the Köppen-Geiger climate classification updated. Meteorol Z 15(3): 259-263

Kryjov VN (2015) October circulation precursors of the wintertime Arctic Oscillation International. Int J Climatol 35:161-171
Lemke P, Ren J, Alley RB, Allison I, Carrasco J, Flato G, Fujii Y, Kaser G, Mote P, Thomas RH, Zhang T (2007) Observations: changes in snow, ice and frozen ground Climate Change 2007: The Physical Science Basis Contribution of Working Group I to the Fourth Assessment Report of the Intergovernmental Panel on Climate Change. Cambridge University Press, Cambridge, pp 337-383

Mestcherskaya AV, Belyankina IG, Golod MP (1995) Snow depth monitoring in the main corn belt of the former Soviet Union during the period of instrumental observations. Izv Acad Sci USSR, Ser Geograph 5:101-110

Morinaga Y, Tian S-F, Shinoda M (2003) Winter snow anomaly and atmospheric circulation in Mongolia. Int J Climatol 23:1627-1636

Panagiotopoulos F, Shahgedanova M, Hannachi A, Stephenson DB (2005) Observed trends and teleconnections of the Siberian High: a recently declining center of action. J Climate 18:1411-1422

Peings Y, Brun E, Mauvais V, Douville H (2013) How stationary is the relationship between Siberian snow and Arctic Oscillation over the 20th century? Geophys Res Lett 40:183-188

Popova V (2007) Winter snow depth variability over northern Eurasia in relation to recent atmospheric circulation changes. Int J Climatol 27: $1721-1733$

Razuvaev VN, Shakirzyanov RI (2000) Changes in procedures of snow observations over the Russian territory. Proc RIHMI-WDC 167:4151 (in Russian)

Rikiishi K, Sakakibara J (2004) Seasonal cycle of the snow coverage in the former Soviet Union and its relation with atmospheric circulation. Ann Glaciol 38:106-114

Saito K, Cohen J (2003) The potential role of snow cover in forcing interannual variability of the major Northern Hemisphere mode. Geophys Res Lett 30:1302

Tachibana Y (1995) A statistical study of the snowfall distribution on the Japan Sea side of Hokkaido and its relation to synoptic-scale and meso-scale environments. J Meteorol Soc Jpn 73:697-715

Veselov VM (2002) PC archives of the State Data Holding and technology of their organization. Proc RIHMI-WDC 170:16-30 (in Russian)

Ward JH (1963) Hierarchical grouping to optimize an objective function. J Am Stat Assoc 58:236-244

Yarnal B (1993) Synoptic climatology in environmental analysis. Belhaven Press, London

Yarnal B, Comrie AC, Frakes B, Brown DP (2001) Developments and prospects in synoptic climatology. Int J Climatol 21:1923-1950

Ye H (2000) Decadal variability of Russian winter snow accumulation and its associations with Atlantic sea surface temperature anomalies. Int J Climatol 20:1709-1728

Ye H (2001a) Quasi-biennial and quasi-decadal variations in snow accumulation over northern Eurasia and their connections to the Atlantic and Pacific Oceans. J Climate 14:4573-4584

Ye H (2001b) Increases in snow season length due to earlier first snow and later last snow dates over north central and northwest Asia during 1937-94. Geophys Res Lett 28:551-554

Ye H, Cho HR, Gustafson PE (1998) The changes in Russian winter snow accumulation during 1936-83 and its spatial patterns. J Climate 11: 856-863

Ye H, Ellison M (2003) Changes in transitional snowfall season length in northern Eurasia. Geophys Res Lett 30:1252 